Reviews

a panchayat. Women are second-class citizens when it comes to finding legal restitution because panchayats are for men only - women are traditionally excluded from attending and participating in a panchayat. Instead, they must find a man to represent them. The ideology and reality of the panchayat is discussed throughout the following chapters.

Chapters 4 through 7 describe various aspects of village disputes, legal discourse and village panchayats.

Through the description in these four chapters, the differences between panchayats and state legal systems are evident. Unlike state courts, panchayats are a process, not an event. The history of the situation and of the interrelationships between disputants is taken into account in panchayats. The aim of the panchayat is compromise, an acceptable, face-saving solution for both parties, rather than finding a winner based solely on the evidence pertaining to a particular case, as happens in state courts. Courts are further alienating in that most lawyers and judges are Hindus or Sikhs, compared with the predominance of Meos in the panchayat. These differences become evident as the reader is lead through various panchayats involving Hunni.

Although the panchayats are the preferred means of pursuing justice, legal pluralism abounds in India. Legal pluralisms are based on religion, caste and state, and justice is accorded by these categories. Moore concretely portrays this pluralism in her descriptions of how panchayats and state courts are played off one another in order to achieve desired legal outcome. Finally, it must also be noted that panchayats are not all identical, specifically in their discourses. Moore outlines a pattern of panchayat discourse that develops over time in a particular panchayat: 1) participants verbally battle to determine who's discourse will set the tone for the panchayat; 2) an elder takes control, hence discourses become more muted and controlled; 3) participants break into small groups to plan their next strategies; 4) groups re-coalesce and continue negotiations.

The final two chapters return to a concepts previously introduced, but are more thoroughly discussed. Chapter 8 examines the gendered experience of justice, how laws treat men and women differently, and how women and men view laws differently. Moore argues that the panchayat is male ideology codified as village law. On the other hand, women's speech does not have a level of community ideology and there is no institution that sanctifies and unifies their words. Chapter 9 returns to the concept of resistance. Here, Moore elaborates on illness as a form of resistance by investigating the role of the maulavi (spiritual healer) in dispute resolution. She argues that the usage of the maulavi by women and the poor indicates their exclusion from panchayats and courts. Moore does address the possibility that illness and attending a maulavi may in fact be compliance, especially because as part of their treatment, women are admonished to be "good" wives/daughter-in-laws/mothers. Although the use of maulavi for dispute resolution was not the focus of this book, its introduction in the last chapter left me wanting more details. How do women perceive their illnesses, and the treatments they receive from the maulavi? This warrants further investigation in order to strengthen arguments regarding resistance as a form of gendered justice.

In sum, I highly recommend this book as an introduction to the reality and complexity of women's legal and social position in North Indian society. There are many points raised by Moore that could foster discussion, and be pursued in further depth in the classroom. This book provides a fine introduction to individuals interested in South Asian ethnography, legal anthropology, and women's studies.

\title{
Myth and Reality in the Rain Forest: How Conservation Strategies are Failing in West Africa, by John F. Oates, Berkeley: University of California Press (1999), xxviii, 310 pp.
}

\section{Reviewed by Jefferson S. Hall, School of Forestry and Environmental Studies, Yale University}

Africa's tropical forest, wildlife populations, and especially his beloved primates are under extreme pressure and John Oates is mad. In fact, John Oates is so mad he decided to write a book to call attention to what he sees as misguided and failed conservation strategies by international conservation organizations and national governments.

Since before 1960, wildlife biologists have been calling attention to the fate of Africa's mammals in an attempt to raise awareness and secure protection for these mammals from extirpation. Out of these early efforts were born some of the first formal conservation efforts on the African continent and, to some degree, wildlife conservation organizations. John Oates' career as a primatologist coincides with the rise of well-known conservation organizations and high profile conservationists. It is therefore not surprising that Oates uses an autobiographical

$40 \quad$ Vol. 72000

Journal of Political Ecology 
Reviews

approach to trace his career and involvement with conservation efforts in Nigeria, Sierra Leone and Ghana (with a side trip to India) to argue how early conservation efforts were transformed, where they went dangerously astray and, in many cases, have ended up as major forces working against conservation.

Oates is not just a Forrest Gump of conservation who has happened to meet famous conservationists. Oates is one of the most well respected primatologists currently working in tropical Africa. While he has worked primarily as an academic studying primates, he has provided conservation organizations with advice informed by three decades' fieldwork experience. For this reason, conservationists and policy makers on both sides of the conservation policy debate should take a careful look at this book.

Oates begins with his early childhood experiences and moves quickly to his early trips to Africa. These early descriptions prove interesting in that they allow the reader to familiarize themselves with someone who is not well known outside academic circles and to convince them that conservation has been a life long commitment. The early descriptions of his work also depict someone who has tended towards the small, modest, and biologically grounded approach to conservation. This is important because it builds the moral podium from which Oates begins his analysis of post-World Conservation Strategy conservation.

Through his involvement in animal collection trips and research projects in Nigeria and India, Oates describes how early conservation efforts were predominantly species based. Over time - while Oates worked in Sierra Leone and Nigeria - conservation strategies became more holistic, at first encompassing ecosystems sans l'homme and then shifting towards empowering local people. As a metaphor for the transition, Oates follows a dramatic shift in policy orientation of the World Wildlife Fund (or World Wide Fund for Nature). He describes how their once science-based conservation efforts shifted with the winds of the time to become predominantly concerned with the well being of local people living in and adjacent to protected areas. The theory goes that local people have lived more or less in harmony with their environment for generations and that if they are empowered, they will do the right thing and protect their environment. This paradigm has become so prevalent that wildlife biologists have often been cast as the bad guys in the conservation struggle - caring more about wild animals than people.

Oates traces how this shift in emphasis made large sums of money available to conservation organizations from international donors. International development behemoths were easily attracted to the notion that improving the living conditions of people living adjacent to areas of interest for biodiversity conservation is the key to conservation. He provides several poignant examples of how the search for money and belief in the people paradigm has often led to the ironic situation where those charged with developing and implementing particular conservation strategies have no idea as to the scientific basis for protecting their given area. Further, they are paid big money to do it!

Oates raises the question of "who are local people?" This, however, does not mean he does not care about local people. His own involvement in the effort to protect Tiwai Island in Sierra Leone is evidence that he feels local people have a role to play in conservation but he does demand that the concept of participation of local people be more carefully defined. Is the best definition of local people really simply those people who have arrived before a particular expatriate conservation worker? What protected area could provide a benefit stream for people throughout a country or even absorb the needs of immigrants coming from hundreds of kilometers away? Finally, what is the correct role of National Governments in defining and implementing conservation strategies within their boarders?

Yet the book has weaknesses too. Oates comes across as having a strong dislike for the World Wide Fund for Nature and holds it up as the most visible practitioner of the conservation policies with which he so disagrees. But what about other conservation organizations? Oates neglects to mention some of the missteps that Wildlife Conservation Society (which has provided him with significant research money) has taken in West and Central Africa. In addition, he seems either unwilling to acknowledge or unaware of the efforts of one of the most visible and vocal conservationists working in tropical Africa that advocates the same conservation philosophy as himself: Steve Gartlen of the World Wide Fund for Nature.

Nevertheless, the weaknesses of the book are far outweighed by the strengths and the development of Oates' heretofore unpopular ideas. Oates shows great courage in taking such a public stance, by giving specific examples of conservation failures and naming names. He will no doubt be personally attacked and opponents of his view will attempt to win the debate by swamping him with voluminous rebuttals. However, most conservation biologists working in tropical Africa have seen similar examples of projects so ill conceived and/or implemented that in practice they have done more harm than good to the biological resource they were designed to protect. Perhaps these colleagues will now engage in a more public discussion, resulting in better conservation in both policy and practice. Oates has succeeded in producing a work that is not just another adventure travel book by a tropical ecologist, but rather a book that will force conservationists and policy makers to take a hard look at the practice of conservation in tropical Africa. 